\title{
Screening of antimicrobial potential and brine shrimp lethality bioassay of the whole plant extract of Spilanthes paniculata Wall. ex DC
}

\author{
Rokeya Siddiqui ${ }^{1 \ddagger}$, Md. Masud Alam¹, Mohammad Ruhul Amin ${ }^{1}$, A. F. M. Shahid-Ud-Daula ${ }^{2}$ and \\ M. M. Hossain ${ }^{2}$ \\ ${ }^{1}$ Department of Microbiology, Noakhali Science and Technology University, Sonapur, Noakhali-3814, \\ Bangladesh; ${ }^{2}$ Department of Pharmacy, Noakhali Science and Technology University, Sonapur, Noakhali- \\ 3814, Bangladesh
}

Received 3 March 2013/Accepted 5 May 2013

\begin{abstract}
Bangladesh possesses a rich flora of medicinal plant. Out of the estimated 5000 species of phanerogams and pteridophytes growing in this country, more than a thousand are regarded as having medicinal properties. The aim of this study was to evaluate the in vitro antimicrobial activity and brine shrimp lethality of the whole plant extracts of Spilanthes paniculata, a plant belonging to the family Asteraceae. The crude extract, n-Hexane, chloroform and ethyl acetate soluble fraction of crude extract showed significant to moderate antimicrobial activity against three Gram positive and three Gram negative microorganisms. The zones of inhibition produced by the crude extract (methanolic extract), n-hexane, choloform and ethyl acetate soluble fractions were found to be $14.89 \mathrm{~mm}-19.40 \mathrm{~mm}$, $14 \mathrm{~mm}-19.40 \mathrm{~mm}, 10.66 \mathrm{~mm}-13.50 \mathrm{~mm}$ and $9.50 \mathrm{~mm}-13.26 \mathrm{~mm}$, consecutively at a concentration of 30 $\mu \mathrm{g} /$ disc. N-Hexane, chloroform and ethyl acetate soluble fractions of methanolic extract of Spilanthes paniculata were screened for antitumor properties using brine shrimp lethality bioassay. From the results of the brine shrimp lethality bioassay, it can be well predicted that n-hexane, chloroform and ethyl acetate soluble fractions of methanolic extract possess mild cytotoxicity on shrimp naupalii. The median lethal concentration ( $\mathrm{LC}_{50}$, the concentration at which $50 \%$ mortality of brine shrimp nauplii occurred) of n-hexane, chloroform and ethyl acetate were $48.978 \mathrm{mg} / \mathrm{ml}, 92.61 \mathrm{mg} / \mathrm{ml}$ and 216.770 $\mathrm{mg} / \mathrm{ml}$, respectively, comparison with positive control vincristine sulphate with $0.839 \mathrm{mg} / \mathrm{ml}$.
\end{abstract}

Key words: Spilanthes paniculata; Antimicrobial activity; Brine shrimp lethality; Cytotoxicity, LC 50

A substantial section of the population of Bangladesh is poor and more than a third of the total population of 150 million people lives below the poverty line (i.e. having a daily income of less than US\$ 1 per day). The poorer section of the population resides mostly in the rural areas and the urban slums. People living in rural areas and in small towns cannot afford the cost of allopathic treatment consequently suffer from proper access to health-care facilities. Therefore, they rely on folk medicinal practitioners also known as Kavirajes for treatment of their various ailments. According to International Union for Conservation of Nature, 5,000 species of angiosperm are reported to occur in Bangladesh. In order to promote the use of medicinal plants as potential sources of medication, it is pertinent to thoroughly investigate their composition and activity and thus validate their use (1). Spilanthes paniculata locally name as Shormoni belongs to genus Spilanthes and family Asteraceae are grown all over Bangladesh Spilanthes paniculata is widely distributed in tropical and sub-tropical regions of the world (2).

${ }^{\ddagger}$ Corresponding Author. Mailing address: Rokeya Siddiqui, Department of Micrrobiology, Noakhali Science and Technology University, Sonapur, Noakhali-3814; Email: rokeya_051@yahoo.com.
The plant grows naturally in damp areas, near lakes or ponds and near sewage discharge areas. It is commonly known as the toothache plant, paracress, eyeball plant and spot plant. Different phytochemicals like alkaloids, glycosides, flavanoids, tannins, anthraquinones, saponins and cardiac glycosides have been reported in Spilanthes paniculata (3). Alkamides are the most abundant phytochemicals present in this plant which account for most of its biological activity. Traditionally, the whole plant is used in the treatment of dysentery (4). In Cameroon, the plant is used as a snakebite remedy and in the treatment of articular rheumatism (5). It is supposed to be useful in cases of tuberculosis (6). In Germany, the plant extract is used for the treatment of soreness or bruising (7). Traditionally flower of Spilanthes paniculata are used in relieve toothache (8), in stomatitis and throat complaints (8), cure paralysis of tongue (9), leaves are used for remedy of stammering (9), as spice (10); local anaesthetic (11), in bacterial and fungal skin diseases (12) and roots are used in cold and flu (5), in headache, asthma and rheumatism (13).

Cancer is one of the most widespread diseases in humans and there is considerable scientific and commercial interest in the continuing discovery of new 
Anticancer agents from natural product. Currently, over $50 \%$ of drugs used in clinical trials for anticancer activity were isolated from natural sources or are related to them (14). A number of active compounds of plant derived phytochemicals have been shown to possess anticancer activity; these include flavonoids, diterpenoids, triterpenoids, and alkaloids (15). A studies showed that Ethanolic extract from root of hydnopytum formicarum Jack., bark of surgada multiflora Bail and stem of Spilanthes paniculata exhibited HDAC(an enzyme involved in carcinogenesis (16) inhibition of $50.5 \%, 40.0 \%, 34.1 \%$ respectively (17).

The aim of the present work was to evaluate the antimicrobial potential and cytotoxicity to support the pharmacological effects and phytochemical investigation of the plant. Although numerous studies have shown the medicinal values of the plants, there still remains ample scope for further in depth research. We disclose herein the antimicrobial and cytotoxic effects of the whole parts of Spilanthes paniculata to further establish the scientific basis of the traditional uses of this plant

\section{MATERIALS AND METHODS}

Bacterial strain. Six gram positive and gram negative bacterial strains were obtained from the stock culture of the Department of Microbiology, Noakhali Science and Technology University, Bangladesh (Table 1). These strains were grown in nutrient broth (Oxoid, USA) for 18 hour at $37{ }^{\circ} \mathrm{C}$ and maintained on agar slant at $4{ }^{\circ} \mathrm{C}$.

TABLE 1. Lists of bacteria used for antimicrobial screening

\begin{tabular}{cc}
\hline Gram negative & Gram positive \\
\hline Escherichia coli & Staphylococcus aureus \\
Vibrio cholera & Bacillus subtilis \\
Salmonella typhi & Bacillus cereus \\
\hline
\end{tabular}

Plant material. The plant Spilanthes paniculata was collected from the Noakhali district, Bangladesh. The plant sample was identified by the experts of Bangladesh National Herbarium, Mirpur, Dhaka, Bangladesh and the identification number is 35400 . The collected whole plant parts were washed with water for several time, separated from undesirable materials and then airdried under shade to protect from sunlight for one week. The dried plant parts were ground into a fine powder with the help of a hammer mill and fine powder was stored in cool and dry place in an airtight container until analysis commenced

Preparation of extract. Whole plant extracts were made by cold extraction method. $400 \mathrm{gm}$ of powdered material was soaked in $1300 \mathrm{ml}$ of $90 \%$ methanol. The container with its contents was sealed and kept for 7 days accompanying occasional shaking and stirring. The whole mixture then underwent a coarse filtration by a piece of clean, white cotton material. Then it was filtered through whatman filter paper (Cat. No. 1440125, Whatman Incorporation, UK) and the filtrate thus obtained was concentrated by using traditional spontaneous natural vaporization method at room temperature. Then, $5 \mathrm{gm}$ of methanolic extract was dissolved in $100 \mathrm{ml}$ of $90 \%$ methanol. This is the mother solution, which was partitioned off successively by three solvents of different polarity such as n-hexane, chloroform and ethyl acetate.

Antibacterial Screening. The total viable bacterial count was carried out by the spread plate technique. The sample $(0.1 \mathrm{ml})$ of each dilution was taken onto each sterile petridish and evenly spread on the solid nutrient medium and incubated at $37^{\circ} \mathrm{C}$ for 24 hours. The plates were screened for the presence of discrete colonies after incubation period and the actual numbers of bacteria were estimated as colony forming unit in per $\mathrm{ml}(\mathrm{cfu} / \mathrm{ml})$. Then the results per dilution were recorded. Ouantitative analvsis for the presence or absence of specific microorganisms was conducted by plating on selective media. Total coliform count (TCC) was done using MacConkey agar medium. All the viable counts were the average of at least three independent experiments. Bacterial isolates were then identified according to the Bergey's manual of determinative bacteriology (17).

Tested bacterial sample from the stock culture were transferred to nutrient agar slants medium. The inoculated slants were then incubated at $37{ }^{\circ} \mathrm{C}$ for $18-24$ hours and then the fresh culture was transferred to the test tube containing nutrient broth to make a uniform suspension of organisms. The bacterial suspension was immediately poured onto nutrient agar plate to give a uniform layer of bacteria. Excess bacterial suspension was taken out with a sterile Pasteur pipette. Impregnated test sample, positive and negative control discs were placed aseptically on the freshly seeded solidified agar plate using sterile forceps. The spatial arrangement of discs were such that the discs were not closer than $20 \mathrm{~mm}$ to the edge of the plate and far enough apart to prevent the overlapping the zone of inhibition. The plates were kept at refrigeration temperature for 3-4 hour for better absorption, during this time microorganisms will not grow but absorption of extract would take place. Finally the plates were incubated upside down at $37^{\circ} \mathrm{C}$ for $12-18$ hours.

TABLE 2. Preparation of test solution

\begin{tabular}{cccc}
\hline Sample & $\begin{array}{c}\text { Amount } \\
(\mathrm{mg})\end{array}$ & $\begin{array}{c}\text { Solvent type } \\
\text { and their volume } \\
(\mathrm{ml})\end{array}$ & $\begin{array}{c}\text { Final } \\
\text { concentrations } \\
(\mu \mathrm{g} / \mu \mathrm{l})\end{array}$ \\
\hline Crude (Methanol) extract & 30 & Methanol,10 & 3 \\
n-Hexane fraction & 30 & n-Hexane, 10 & 3 \\
Ethylacetate fraction & 30 & Ethyl acetate, 10 & 3 \\
Chloroform fraction & 30 & Chloroform, 10 & 3 \\
\hline
\end{tabular}

Brine shrimp lethality bioassay. Brine shrimp lethality bioassay is used for screening of general toxic properties, which also indicates a range of bioactivities such as anticancer, antiviral and pesticidal properties. The brine shrimp lethality bioassay of the methanolic n-hexane, ethylacetate and chloroform extract of whole plant of Spilanthes paniculata were evaluated according to Meyer protocol (19) against the Artemia salina as a test organism to monitor the cytotoxicity of a compound. In this lethality bioassay, the $\mathrm{LC}_{50}$ values was estimated with $95 \%$ confidence intervals for statistically significant comparisons of potencies.

Hatching of brine shrimps. Thirty eight gram sea salt (pure $\mathrm{NaCl}$ ) was weighed, dissolved in one litre of distilled water and filtered off to get clear solution. Seawater was taken in the small tank and Artemia salina leach (brine shrimp eggs) was added to one side of the tank and then this side was covered. Two days were allowed to hatch the shrimp and to be matured as nauplii. Constant oxygen supply was provided throughout the hatching time. The hatched shrimps were attracted to the lamp through the perforated dam and with the help of a Pasteur pipette 10 living shrimps were added to each of the vials containing $5 \mathrm{ml}$ of seawater.

Preparation of different concentration of n-hexane, ethylacetate and chloroform soluble fraction of methanolic extract of Spilanthes paniculata. Different concentration of extract were prepared by dissolving them in DMSO to attain a concentration of $0.78125,1.5625,3.125,6.25,12.50,25,50,100,200$ and $400 \mu \mathrm{g} / \mathrm{ml}$. Then $100 \mu \mathrm{l}$ of each concentration of different extracts were added to 5 $\mathrm{ml}$ simulated seawater-shrimp naupalii.

Preparation of positive control and negative control group for leathality bioassay. Vincristine sulphate was used as the positive control. Measured amount of the vincristine sulphate was dissolved in DMSO to get an initial concentration of 40 $\mu \mathrm{g} / \mathrm{ml}$ from which serial dilutions were made using DMSO to get $20 \mu \mathrm{g} / \mathrm{ml}, 10$ $\mu \mathrm{g} / \mathrm{ml}, 5 \mu \mathrm{g} / \mathrm{ml}, 2.5 \mu \mathrm{g} / \mathrm{ml}, 1.25 \mu \mathrm{g} / \mathrm{ml}, 0.625 \mu \mathrm{g} / \mathrm{ml}, 0.3125 \mu \mathrm{g} / \mathrm{ml}$ and 0.15625 $\mu \mathrm{g} / \mathrm{ml}$. Then the positive control solutions were added to the premarked vials containing ten living brine shrimp nauplii in $5 \mathrm{ml}$ simulated sea water to get the positive control groups. $100 \mu \mathrm{l}$ of each solvents (n hexane, ethylacetate and chloroform) was added to pre marked glass vials containing $5 \mathrm{ml}$ of simulated sea water and 10 shrimp nauplii to use as negative control groups. If the brine shrimps in these vials showed a rapid mortality rate, then the test was considered as invalid as the nauplii died due to some reason other than the cytotoxicity of the compounds. After $24 \mathrm{~h}$, the vials were inspected using a magnifying glass and the number of survived nauplii in each vial was counted. The mortality endpoint of this bioassay was defined as the absence of controlled forward motion during 30 s of observation. From this data, the percent (\%) of mortality of the brine shrimp nauplii was calculated for each concentration using the following formula.

\section{Mortality $=\mathrm{N}_{\mathrm{t}} / \mathrm{N}_{0} \times 100$}

Where, $\mathrm{N}_{\mathrm{t}}=$ Number of killed nauplii after 24 hrs of incubation,

$\mathrm{N}_{\mathrm{o}}=$ Number of total nauplii transferred i.e. 10 .

The $\mathrm{LC}_{50}$ (Median lethal concentration) was then determined using Regression analysis. 
TABLE 3. Antimicrobial activity of the crude sample, n-Hexane, chloroform and ethyl acetate soluble fractions of Spilanthes paniculata

\begin{tabular}{|c|c|c|c|c|c|c|c|}
\hline \multirow{2}{*}{\multicolumn{2}{|c|}{ Bacterial strains }} & \multicolumn{6}{|c|}{ Diameter of zone of inhibition in $\mathrm{mm}$} \\
\hline & & $\begin{array}{c}\text { Crude } \\
\text { sample }\end{array}$ & n-Hexane & Chloroform & $\begin{array}{c}\text { Ethyl } \\
\text { acetate }\end{array}$ & $\begin{array}{l}\text { Negative control } \\
\text { (Solvents) }\end{array}$ & $\begin{array}{l}\text { Positive control } \\
\text { (Kanamycin) }\end{array}$ \\
\hline \multirow{3}{*}{$\begin{array}{l}\text { Gram } \\
\text { negative }\end{array}$} & Escherichia coli & $15.28 \pm 0.22$ & $14.00 \pm 0.32$ & $13.40 \pm 0.35$ & $11.70 \pm 0.13$ & 0 & $17.90 \pm 0.15$ \\
\hline & Vibrio cholerae & $15.80 \pm 0.55$ & $16.50 \pm 0.13$ & $11.60 \pm 0.25$ & $10.70 \pm 0.15$ & 0 & $25.13 \pm 0.12$ \\
\hline & Salmonella typhi & $14.89 \pm 0.45$ & $14.70 \pm 0.15$ & $10.66 \pm 0.40$ & $11.40 \pm 0.25$ & 0 & $17.50 \pm 0.15$ \\
\hline \multirow{3}{*}{$\begin{array}{l}\text { Gram } \\
\text { positive }\end{array}$} & Bacillus cereus & $15.25 \pm 0.45$ & $16.21 \pm 0.22$ & $13.50 \pm 0.48$ & $10.10 \pm 0.12$ & 0 & $21.60 \pm 0.25$ \\
\hline & Bacillus subtilis & $15.50 \pm 0.48$ & $17.68 \pm 0.25$ & $12.50 \pm 0.32$ & $13.26 \pm 0.22$ & 0 & $22.10 \pm 0.34$ \\
\hline & Staphylococcus aureus & $19.40 \pm 0.50$ & $19.40 \pm 0.18$ & $11.15 \pm 0.28$ & $9.50 \pm 0.21$ & 0 & $22.38 \pm 0.26$ \\
\hline
\end{tabular}

TABLE 4. Effect of n-hexane, chloroform and ethyl acetate soluble fraction of Spilanthes paniculata on shrimp nauplii

\begin{tabular}{|c|c|c|c|c|c|c|c|c|c|c|}
\hline \multirow{2}{*}{$\begin{array}{c}\text { Test Sample } \\
\text { Conc. }(\mathrm{C}) \\
(\mu \mathrm{g} / \mathrm{ml})\end{array}$} & \multirow[b]{2}{*}{$\log C$} & \multicolumn{3}{|c|}{$\begin{array}{c}\text { \% Mortality of solvent extract of crude } \\
\text { test sample }\end{array}$} & \multicolumn{3}{|c|}{ Positive Control (vincristine sulphate) } & \multicolumn{3}{|c|}{ Negative Control (Solvents) } \\
\hline & & n-Hexane & $\begin{array}{l}\text { Ethyl } \\
\text { acetate }\end{array}$ & Chloroform & $\begin{array}{l}\text { Conc. }(\mathrm{C}) \\
(\mu \mathrm{g} / \mathrm{ml})\end{array}$ & $\log C$ & $\%$ Mortality & $\begin{array}{c}\text { Conc. } \\
(\mathrm{C}) \\
(\mu \mathrm{g} / \mathrm{ml})\end{array}$ & $\log C$ & $\%$ Mortality \\
\hline 400 & 2.602 & 100 & 100 & 100 & 40 & 1.602 & 100 & 400 & 2.602 & 0 \\
\hline 200 & 2.301 & 100 & 80 & 50 & 20 & 1.301 & 90 & 200 & 2.301 & 0 \\
\hline 100 & 2 & 100 & 0 & 40 & 10 & 1.000 & 90 & 100 & 2 & 0 \\
\hline 50 & 1.699 & 10 & 0 & 30 & 5 & 0.698 & 80 & 50 & 1.699 & 0 \\
\hline 25 & 1.398 & 0 & 0 & 30 & 2.5 & 0.397 & 70 & 25 & 1.398 & 0 \\
\hline 12.5 & 1.097 & 0 & 0 & 20 & 1.25 & 0.096 & 70 & 12.5 & 1.097 & 0 \\
\hline 6.25 & 0.796 & 0 & 0 & 10 & 0.625 & -0.204 & 50 & 6.25 & 0.796 & 0 \\
\hline 3.125 & 0.495 & 0 & 0 & 0 & 0.3125 & -0.505 & 30 & 3.125 & 0.495 & 0 \\
\hline 1.5625 & 0.194 & 0 & 0 & 0 & 0.15625 & -0.806 & 20 & 1.5625 & 0.194 & 0 \\
\hline 0.78125 & -0.107 & 0 & 0 & 0 & 0.078125 & -1.107 & 10 & 0.78125 & -0.107 & 0 \\
\hline
\end{tabular}

\section{RESULTS}

Antimicrobial test. The result of the antimicrobial activity was measured in terms of the diameter of zone of inhibition in $\mathrm{mm}$ (Millimeter) with standard deviation (Table 3). The crude sample (methanolic extract), n-Hexane, chloroform and ethyl acetate soluble fractions were used for antimicrobial activity in single concentration $30 \mu \mathrm{g} / \mathrm{disc}$. The crude extract showed significant activity against Escherichia coli $(15.28 \mathrm{~mm})$, Salmonella typhi $(14.89 \mathrm{~mm})$ and Staphylococcus aureus $(19.40 \mathrm{~mm})$, moderate activity against Bacillus cereus $(15.25 \mathrm{~mm})$, Bacillus subtilis $(15.50 \mathrm{~mm})$ and mild activity against Vibrio cholera $(15.80 \mathrm{~mm})$. The $\mathrm{n}$-hexane soluble fraction exhibited significant activity against Escherichia coli (14.00 $\mathrm{mm})$, Salmonella typhi $(14.70 \mathrm{~mm})$, Bacillus subtilis $(17.68 \mathrm{~mm})$, and Staphylococcus aureus $(19.40 \mathrm{~mm})$. The n-hexane soluble fraction showed moderate activity against Bacillus cereus $(16.21 \mathrm{~mm})$, and Vibrio cholera $(16.50 \mathrm{~mm})$. The chloroform soluble fraction exhibited significant activity against Escherichia coli $(13.40 \mathrm{~mm})$ and moderate activity against Salmonella typhi $(10.66 \mathrm{~mm})$, Bacillus subtilis $(12.50 \mathrm{~mm})$, and Bacillus cereus $(13.50 \mathrm{~mm})$. The chloroform soluble fraction showed mild activity against Staphylococcus aureus $(11.15 \mathrm{~mm})$ and Vibrio cholera $(11.60 \mathrm{~mm})$. The ethyl acetate soluble fraction exhibited moderate activity against Escherichia coli $(11.60 \mathrm{~mm})$, Bacillus subtilis $(13.26 \mathrm{~mm})$ and Salmonella typhi $(11.40 \mathrm{~mm})$, and showed mild activity against rest of all test organisms.
Brine shrimp lethality bioassay. In the present bioactivity study, the n-hexane, ethyl acetate and chloroform fractions of methanolic extract showed positive results indicating that the test samples were biologically active (Table 4). Each of these test samples showed different mortality rates at different concentrations. Plotting of $\log$ of concentration versus percent mortality for these test samples showed an approximate linear correlation (Figure 1). From the graphs, the median lethal concentration $\left(\mathrm{LC}_{50}\right.$, the concentration at which $50 \%$ mortality of brine shrimp nauplii occurred) was determined for the samples. The positive control groups showed nonlinear mortality rates at lower concentrations and linear rates at higher concentrations. There was no mortality in the negative control groups indicating the test as a valid one and the results obtained are only due to the activity of the test agents (Table 4).

The $\mathrm{LC}_{50}$ values of the $\mathrm{n}$-hexane, chloroform and ethylacetate soluble extracts are $48.978 \mu \mathrm{g} / \mathrm{ml}, 92.61$ $\mu \mathrm{g} / \mathrm{ml}$ and $216.770 \mu \mathrm{g} / \mathrm{ml}$ respectively on shrimp nauplii. The $\mathrm{LC}_{50}$ values for positive control vincristine sulfate is $0.839 \mu \mathrm{g} / \mathrm{ml}$. Comparison with the positive control indicates that $\mathrm{n}$-hexane, chloroform and ethylacetate soluble fraction of methanolic extracts have mild antitumour activitiy. n-Hexane soluble fractions has a highest antitumour activity than ethyl acetate and chloroform soluble fractions of methanolic fractions.

\section{DISCUSSION}

Different solvent extracts of spillanthes peniculata showed significant activity against a number of Gram 


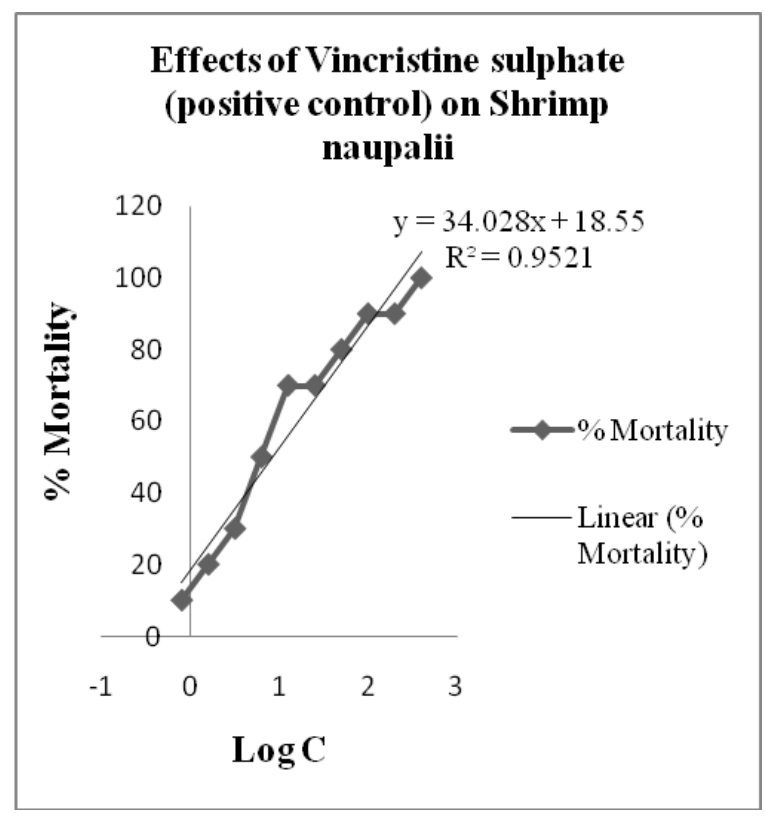

(a)

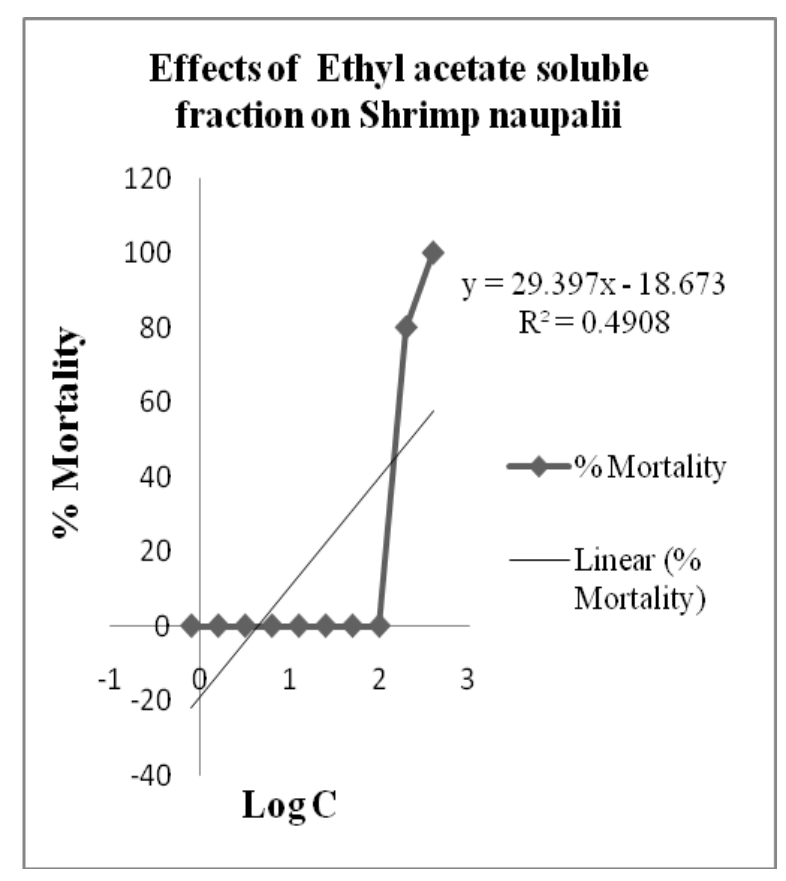

(c)

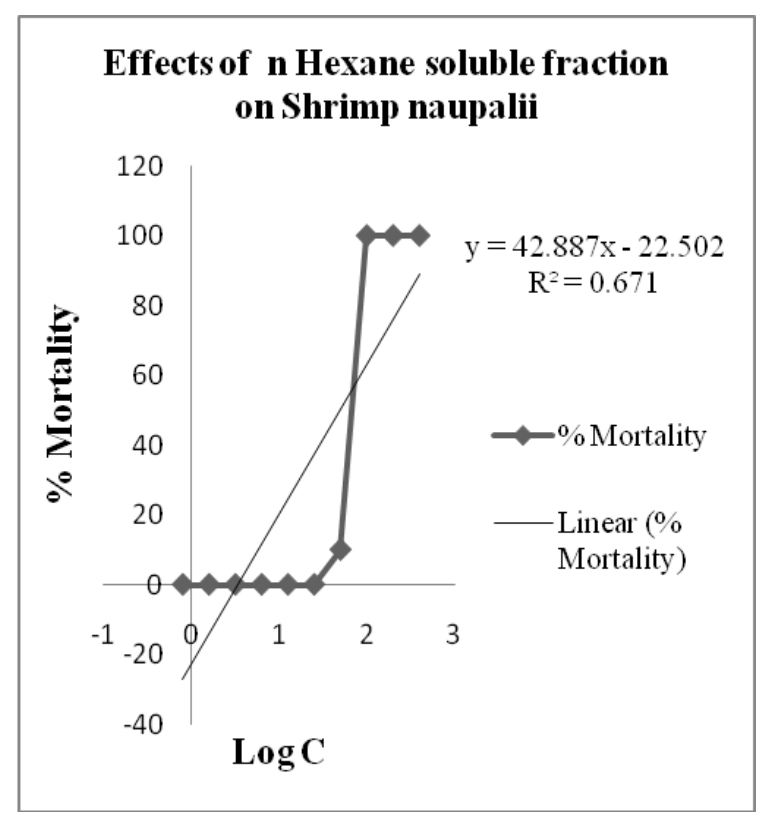

(b)

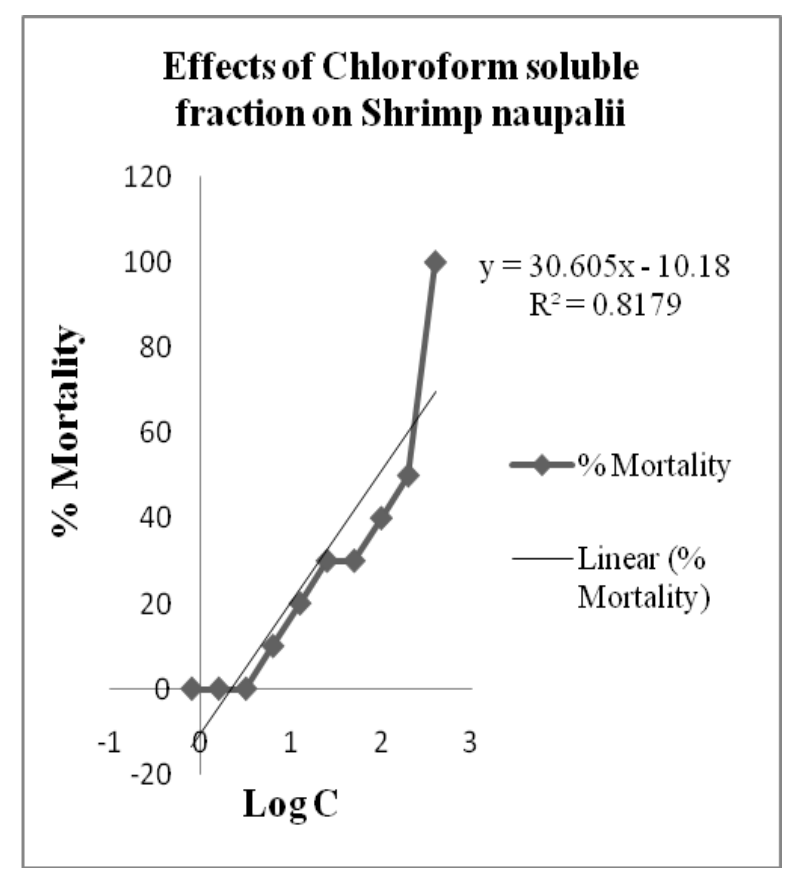

(d)

FIG. 1. Effect of test samples at different concentration on shrimp naupalii. a). Vincristine sulphate; b). n-Hexane soluble fraction; c). Ethyl acetate soluble fraction; d). Chloroform soluble fraction 
positive and Gram negative bacteria. Agharkar (20) reported that the flower heads are chewed to relieve the toothache and other mouth related troubles and leaves are used externally in treatment of skin diseases. The present investigation supported the antibacterial property of the whole plant towards tested pathogens involved in various infectious diseases. The phytochemical evaluation of Spilanthes paniculata showed that alkaloids, triterpenoids and phenolics were present in active methanol extract (21). The presence phytocemicals like that alkaloids, triterpenoids and phenolics might be responsible for the antibacterial activity of whole plant extract. The present result supported the ethnobotanical role of this plant in controlling infectious diseases as reported by Agharkar and Verma et al., $(20,22)$. Purification and characterization of active ingredients followed by a detailed study of toxicity and pharmacological effects of the compounds are necessary prior to its medicinal application.

The brine shrimp lethality assay has been used routinely in the primary screening of the extracts as well as isolated compounds to assess the toxicity towards brine shrimp, which could also provide an indication of possible cytotoxic properties of the test materials. Brine shrimp nauplii have been previously utilized in various bioassay systems. Among these applications have been the analyses of pesticidal residues, mycotoxins, stream pollutants, anesthetics, dinoflagelate toxins, morphinelike compounds, carcinogenicity of phorbol esters and toxicants in marine environment. A number of novel antitumor and pesticidal natural products have been isolated using this bioassay by the workers $(23,19$, and 24). The brine shrimp test correlates reasonably well with cytotoxic and anti-tumour properties Kinghorn (25) and Fouche (26). From the results of the brine shrimp lethality bioassay showed that the n-hexane, chloroform and ethyl acetate soluble fraction possess cytotoxic activity comparison with positive control vincristine sulfate. The variation in brine shrimp lethality assay results (Table 4) may be due to the difference in the amount and kind of cytotoxic substances (e.g. tannins, flavonoids or triterpenoids) present in the extracts and it signifies that the cytotoxicity exhibited by these soluble fractions might have mild antitumor and pesticidal activity.

The present study indicates that the extracts of Spilanthes paniculata (methanolic, n-hexane, chloroform and ethyl acetate) have profound antimicrobial and mild cytotoxic effect. From the previous studies by Trikunakornwong et al. (27) and our current investigation it may be concluded that the flavonoids and tannins are responsible for aforementioned activity. This novel finding will aid us to conduct bioactivity guided isolation and characterization of leading compounds in due course.

\section{REFERENCES}

1. Nair, R., and S. Chanda. 2006. Activity of some medicinal plants against certain pathogenic bacterial strains. Indian J. Pharmacol. 38: 142-144

2. Jansen, R. K. 1981. Systematics of Spilanthes (Compositae: Heliantheae). J. Syst. Bot. 6 (3): 231-257.

3. Shanthi, P. and P. Amudha. 2010. Evaluation of the phytochemical constituents of Acmella calva (DC) R.K.Jansen. Int J Pharma Bio. Sci. 1 (4): B308-B314.

4. Fabry, W., P. O. Okemo, and R. Ansorg. 1998. Antibacterial activity of East African medicinal plants. J. Ethnopharmacol. 60 (1): 79-84.

5. Santesson, C. G. 1976. Several drugs of the Cameroon District and their native uses. Arkiv für. Bot. 20A: 1-34.

6. Storey, C., and J. I. Salem. 1997 Lay use of Amazonian plants for the treatment of tuberculosis. J. Acta. Amaz, 27 (3): 175-182.

7. Frahm, E., and K. Gudat. 1980. Percutaneous treatment of acute sport injuries with an extract of Spilanthes paniculata. Therapiewoche 30 (48): $8186-8190$.

8. Deka, P., and Kalita, M. C. 2005. In vitro clonal propagation and organogenesis in Spilanthes acmella (L.) Murray: A herbal pesticidal plant of north-east India. J. Plant Biochem. Biotechnol. 14: 69-71.

9. Council of Scientific Industrial Research. 1976. The wealth of India, raw materials. New Delhi: Publication and Information Directorate, Council of Scientific Industrial Research 2: 11-12.

10. Ospina, D., L. S. Nigrinis, J. Olarte, and O. E. Nunez. 1986. Phytopharmacologic study of flower lipid soluble fractions from Spilanthes americana (Mutis). Part 1. Phytochemical study. Revista Colombiana de Ciencias Quimico-Farmaceutics 15: 37-47.

11. Senthilkumar, P., S. Paulsamy, K. K. Vijayakumar, and K. Kalimuthu. 2007. In vitro regeneration of the medicinal herb of Nilgiri shola, Acmella calva L. from leaf derived callus. Plant Tissue Cult. Biotech. 17 (2): 109-114.

12. Tan, C. L., B. H. Ang, and L. K. Chan. 2004. Effect of reduced N6Benzyladenine, explant type, explant orientation, culture temperature and culture vessel type on regeneration of adventitious shoot and in vitro plantlets of Spilanthes acmella. J. Plant Biol. 47 (1): 15-20.

13. Tiwari, H. P., and A. Kakkar. 1990. Phytochemical examination of Spilanthes acmella Murr. J. Indian Chem. Soc. 67 (9): 784-785

14. Newman, D. J., and G. M. Cragg. 2007. Natural products as sources of new drugs over the last 25years. J Nat Prod. 70: 461-77.

15. Han, H. J., et al. 2008. Natural inhibitors of DNA topoisomerase I with cytotoxicities. Chem. Biodivers. 5: 1364-68.

16. Zhang, Z., et al., 2005. Quantitation of HDAC1 mRNA expression in invasive carcinoma of the breast. Breast Cancer Res. Treat. 94 (1): 11-6.

17. Rani, S. A., and S. U. Murty. 2006. Antifungal potential of flower head extract of spilanthes acmella (Linn). African J. Biomed. Res. 26: 67-69.

18. Bauer, A., and C. Thornsberry. 1985. Susceptibility tests: Diffusion test procedures, p. 978-979. In E. H. Lannette, A. Balows, W. J. Housler, and H. J. Shadomy (eds.); Manual of microbiology, $4^{\text {th }}$ ed. American Society for Microbiology, Washington, D. C.

19. Meyer, B. N., et al. 1982. Brine shrimp: a convenient general bioassay for active constituents. Planta Med. 45: 31-32.

20. Agharkar, S. P. 1991. Medicinal plants of Bombay presidency. Scientific Publishers, Jodhpur, India.

21. Thomas, T. 2011. Antibacterial action of gradient extracts of flower heads of Spilanthes paniculata Wall. Ex DC. Plant Sciences Feed 1: 186 - 189).

22. Verma, D. M., N. P. Balakrishnan, and R. D. Dixit. 1993. Flora of Madhya Pradesh. Botanical survey of India, Kolkata, India.

23. McLaughlin, J., C. Chang, and D. Smith. 1991. Proceedings of the 18th national seminar and Unesco workshop on natural products. Institute of Advance Studies, University of Malaysia, Malaysia.

24. Sam, T. W. 1993. Toxicity testing using the brine shrimp: Artemia salina. In S. M. Colgate, and R. J. Molyneux (ed.), Bioactive natural products: Detection, isolation and structural determination. CRC Press, USA.

25. Kinghorn, A. D., et al. 2003. Novel strategies for the discovery of plantderived anticancer agents. Pharm. Biol. 41: 53-67.

26. Fouche, G., et al. 2008. In vitro anticancer screening of South African plants. J. Ethnopharmacol. 119: 455-61.

27. Trikunakornwong, A., N. Sriubolmas, W. De-Eknamkul, and N. Ruangrungsi. 1999. Chemical composition and antimicrobial activity of essential oils from Thai Spilanthes paniculata and S. acmella. 25th Congress on Science and Technology of Thailand. Phitsanulok, Thailand. 